821.163.41.09-32 Андрић И. https://doi.org/10.18485/kij.2020.67.2.5

МАГДА Г. МИЛИКИТ, докторанд* Универзитет у Београду Филолошки факултет
Оригинални научни рад

Примљен: 15.09.2020.

Прихваћен: 14.12.2020.

\title{
ЕТНИЧКИ ИДЕНТИТЕТИ У АНДРИЋЕВОЈ ПРИПОВЕЦИ „ТРИ ДЕЧАКА”**
}

\begin{abstract}
Тема Андрићеве приповетке „Три дечака” (1947), коју аутор није сврстао у сабрана дела, јесте суревњивост међу припадницима различитих етнитета у Сарајеву с краја 19. века. У раду се на причу примењује имаголошки метод, тако што се на плану нарације анализира (језички) конструкт процеса имагинирања етничких идентитета ликова. Истраживање је замишљено као симбиоза неколиких наука и научних дисциплина: заснива се на социолошкој, етнопсихолошкој, филозофској и књижевнотеоријској мисли. На основу тумачења приповедних одлика, настојаћемо да утврдимо да су представе о ентитетима у Босни стереотипни или аутор стереотипе о њима успева да превреднује.
\end{abstract}

Кључне речи: Иво Андрић, „Три дечака”, имагологија, етнички идентитет, религија, приповедни поступак.

Непоколебљив, Дефосе доказује да овај крај, иако умртвљен и одвојен од света, није пустиња него напротив разнолик, у сваком погледу занимљив и на свој начин речит; народ је, истина, подељен на вере, пун сујеверја, подвргнут најгорој управи на свету и стога у многоме заостао и несрећан, али у исто време пун духовних богатстава, занимљивих карактерних особина и чудних обичаја; у сваком случају, вреди потрудити се и испитивати узроке несреће и заосталости.

По неколико пута у дану Давил побегне у своју 'стварност на хартији', наслони се, у себи, на неку мисао из епа, као хром на штаку.

(Иво Андрић, Травничка хроника)

Историја Босне и различити аспекти живота у њој често су тематизовани у делу Иве Андрића, писца који је за ову земљу везан пре свега рођењем, детињством и раном младошћу. Проблеми идентитета, Сопства и Другости, индивиду-

${ }^{*}$ magdamilikic95@gmail.com

** Рад је настао на основу излагања на ХІ научном скупу младих филолога Србије, који је одржан на Филолошко-уметничком факултету у Крагујевцу, 30. марта 2019. године. 
алног и колективног, Истока и Запада искрсавају у Андрићевим остварењима: у романима Травничка хроника, На Дрини ћуприја, Проклета авлија, у недовршеном остварењу Омермаша Латас; у приповеткама „Ћоркан и Швабица”, „За логоровања”, „Мустафа Маџар”, „љубав у Касаби”, „Писмо из 1920. године” и бројним другим; затим у есејима, путописима о Португалу и Шпанији; као и у докторској дисертацији Развој духовног живота у Босни под утииајем турске владавине.

У раду ћемо интерпретирати наративну стратегију у приповеци „Три дечака", односно њене импликације на изградњу етничких идентитета у овом делу, које аутор сматра „скицом”, због чега га није сврстао у сабрана дела (Палавестра 1997: 18). Прича је настала после Другог светског рата, 1947. године, за време пишчевог боравка у Сарајеву. Палавестра пише да је Андрић био свестан „чудног психичког и стваралачког узнемирења у сарајевском раздобљу (1945-1950)" и да је „обузет необичним и претећим слутњама, осећао да се нешто дешава у његовој имагинацији, па је неке приповетке и записе из тог времена ('Ноћни разговор из 1941', 'Тај дан', 'Сан', 'Три дечака')” (Палавестра 1997: 19) оставио на страну и никад их више нигде није прештампао. Стога је један од наших циљева и да у литерарном смислу вреднујемо ову причу, која је до сада измицала пажњи Андрићевих тумача.

\section{Очеви и деца}

Радња приповетке смештена је у Сарајево, у време аустроугарске управе у Босни и Херцеговини, и то на дан посете аустроугарског престолонаследника Рудолфа и његове супруге Стефаније Сарајеву (1888. год.). Средишња тема дела је узајамна суревњивост међу припадницима неколиких етни(ци)тета у овом мултиетничком месту. Очеви различитог порекла су у (латентном) сукобу, али, чини се, у тексту постоје назнаке становишта да ће синови превредновати антагонистички образац поимања Другости.

Социолог Ричард Сенет сматра да „најједноставнији начин стварања индентитета заједнице јест онај који дјелује кад је угрожен сам опстанак групе, као у рату или некој другој катастрофи" (према Брајовић 2007: 135). Период аустроугарске управе у Босни и Херцеговини (1878-1918), свакако, турбулентан је и кризан за саморазумевање и самопоимање човека са овог простора. Обратимо стога пажњу на први параграф у делу, у ком наратор описује неуобичајену атмосферу у Сарајеву на дан доласка високих званичника:

„Тога дана није се нико могао пожалити на једноличност и досаду сарајевског времена. Ако су дотад сви дани личили један на други, тај је био заиста испуњен узбудљивим новостима. Већ од самог јутра у трафикама су продаване службене новине са црвено-жутим оквиром, са босанским грбом у заглављу и крупним написом: добро нам дошли велики гости! Било је и стихова" (Андрић 2012: 286). 
У студији Наџионални идентитет социолог Антони Смит као „битна обележја националног идентитета”, истиче и „заједничку масовну, јавну културу” (Смит 1998: 29). Застава је изданак културе једне државе и служи за идентификацију њених становника, пре свега, са људима са конкретне државне територије. Црвено-жути оквир из навода представља стандардизовану заставу земље која је под управом Аустроугарске. Даље, у истој реченици сазнајемо да у заглављу насловне стране стоји босански грб, што је вид (о)чувања првобитног културног и националног идентитета босанског човека. У цитату из приче се, дакле, у виду синтезе аустроугарских и босанских карактеристика, открива двојност, „контаминираност" идентитета ондашњег становништва.

Неколико кратких, „дискретних” исказа наратора сугеришу да сарајевски живаљ има отклон од претензија Двојне монархије. О томе сведочи и наредни сегмент: „У ваздуху има неког хладног узбуђења"” (Андрић 2012: 286). Метафорички употребљен епитет „хладан” имплицира дистанцу сарајевског човека према „гостима”, односно према држави под чијом је управом. У том погледу индикативан је и следећи цитат: „Кад су одједном почели да грувају топови са тврђава које окружују Сарајево, уска долина се испунила заглушним тутњем и све живо неким уплашеним узбуђењем као пред стихијом природних појава. У исти мах одјекнуше звона са цркава, прво с једне, па са друге, све јаче и јаче; звукови су им се сударали не мешајући се и ширећи језу узбуђеља кроз заталасани ваздух" (Андрић 2012: 286).У овом одељку долазак аустроугарског престолонаследника доводи се у везу са апокалиптичном представом; посета престолонаследника, дакле, изазива велики страх код Сарајлија.

Весна Голдсворти у књизи Измишљање Руританије, на основу превасходно литерарних текстова испитује како Западна Европа и амерички континент виде Балкан. Голдсвортијева на самом почетку истраживања исписује куриозитет који може бити знаковит за нашу анализу:

„Балкан је такође, што је прилично неуобичајено за географска имена, подстакао творбу глагола. Тако, на пример, Balkanisieren на немачком, balkaniser на француском, balkanizzare на италијанском, или to balkanise на енглеском, значи поделити на бројне мање и често узајамно непријатељске јединице као што је учињено крајем 19. и почетком 20. века. Појам 'балканизација' користи се у пренесеном значењу у различитим контекстима као симбол претеће поделе" (Голдсворти 1998: 5).

У различитим језицима поникао је, дакле, глагол који синтетише „пројектовани аутостереотип" ${ }^{2}$ о Балкану, по ком је ово подручје Источне Европе корен великих светских сукоба, али и локалних, мотивисаних такозваним „анимозитетом малих разлика”. У приповеци „Три дечака” се донекле схематизовано - и самим тим поједностављено - приказује коегзистенција различитих етнитета у Сарајеву с краја 19. века, тако што се (барем „површински” гледано) изграђује стере-

\footnotetext{
${ }^{1}$ Курзивна истицања у овом и свим наредним цитатима из приповетке не припадају аутору, већ су накнадна, тј. наша - М. М.

${ }^{2}$ Примењујемо класификацију стереотипа Клауса Рота (в. Рот: 2011).
} 
отипна слика: припадници различитих конфесионалних група међусобно се не мешају, не комуницирају, већ су у извесном смислу сепаратизовани:

„Безбројна деца разног узраста и различитог одела поврвила су са обале и као поточићи после пљуска губила се у свима правцима, по махалама, а ту су се опет делила и у све мањим и мањим групама одлазила у своје сокаке.

У стрми, кратки и кривудави Дедагин сокак ушла су истовремено, истовремено али не заједно, три дечака. Једно је био син Авдаге Сенабије, друго Петра Мајсторовића, треће удовице Маре Чолићеве која је куварица у Катехетском дому” (Андрић 2012: 286).

Наведени одељак из приче оправдава становиште Весне Голдсворти и тако се, између осталог, потврђује да су стереотипи веома стабилне представе (али не и да је њихов садржај безупитна истина о односима међу припадницима различитих етнитета на Балкану). Док у студији Голдсвортијеве немамо недоумица у вези са врстом стереотипа, у Андрићевом остварењу ствар је нешто комплекснија. Да бисмо одредили тип стереотипа, требало би да промислимо о перспективи из које казивач говори, односно требало би да помније тумачимо наративни поступак у делу.

У наредном одељку из приповетке предочава се атмосфера у граду након параде: „Те ноћи је сјало Сарајево у ватрама сваке врсте. Од оног судбоносног дана пре стотине година, кад су трупе принца Евгенија Савојског запалиле овај град, пре него што ће се повући из њега, није било оволико огња и сјаја по граду и око њега" (Андрић 2012: 287). Босна је крајем 17. века претрпела тортуру аустријског империјализма, да би након Берлинског конгреса потпала под власт, условно речено, истог народа. Приповедач - који је врло обавештен о историјској прошлости Босне - сугерише да је иронија историје у томе што је 1697. године аустријска војска палила босанска насеља, док 1888. „огањ и сјај” чине део свечаности на дочеку представника Аустроугарске, тадашњег окупатора ове земље. Како је сусрет Босне са Другошћу у поменутом случају био кобан, очекивано је - као да сугерише казивач - да човек с овог тла стрепи од сваке врсте Другости. У том смислу, у причи као да је наговештена приповедачева „емпатија” према ликовима који гаје неку врсту анимозитета према суграђанима друге вероисповести.

Ако претпоставимо да је Сарајево с краја 19. века било налик вароши, суревњивост међу ликовима можемо једним делом објаснити и „философијом паланке”, коју у истоименој студији излаже Радомир Константиновић, премда овај аутор паланку поима као нешто шири појам. Константиновић сматра да паланка има „жељу за једнообразношћу, за продирањем свуда, за апсорбовањем свега” (Константиновић 2006: 8); она настоји да елиминише све „што би њој било непознато, што би остало 'тајна' за њу, ван домашаја њеног ока, слуха и могућности делања” (Константиновић 2006: 8). Ликови у причи „Три дечака” различите су вероисповести, па је достизање ,једнообразности” у том аспекту онемогућено. Обред и начин исповедање вере Авдаге Сенабије је „ван домашаја ока” Петра Мајсторовића, и обратно. На исти начин се донекле може објаснити и „хладно узбуђење” сарајевског живља у причи приликом посете аустроугарских пред- 
ставника. Долазак престолонаследника Рудолфа и Стефаније представља продор непознатог, новог, мистериозног у простор познатог, сарајевског, босанског. Средишњи мотив приповетке „Три дечака” је, заправо, латјмотив целокупног Андрићевог стваралаштва. На пример, и у чувеној приповеци „Писмо из 1920. године" (1946) проблематизује се анимозитет међу Сарајлијама различите вероисповести, што показује и њен наредни сегмент из писма Макса Левенфелда:

„Ко у Сарајеву проводи ноћ будан у кревету, тај може да чује гласове сарајевске ноћи. Тешко и сигурно избија сат на католичкој катедрали: два после поноћи. Прође више од једног минута (тачно седамдесет и пет секунди, бројао сам) и тек тада се јави нешто слабијим али продорним звуком сат са православне цркве, и он искуцава своја два сата после поноћи. Мало за њим искуца промуклим, далеким гласом сахат-кула код Бегове џамије, и то искуца једанаест сати, аветињских турских сати, по чудном рачунању далеких, туђих крајева света! Јевреји немају свога сата који искуцава, али бог једини зна колико је сада сати код њих, колико по сефардском, а колико по ешкенаском рачунању” (Андрић 2012: 236).

Исказ истог значења налазимо на почетку приче „Три дечака”, где се описује долазак престолонаследника и његове супруге: „У исти мах одјекнуше звона са цркава, прво с једне па са друге, све јаче и јаче; звукови су им се сударали не мешајући се ширећи језу узбуђења кроз заталасан ваздух" (Андрић 2012: 286). У раду смо већ навели и део из „Три дечака” у ком се наглашава да су се сарајевска деца, након параде и дочека царских гостију, „делила и у све мањим групама одлазила у своје сокаке”, те су у Дедагин сокак ушла „истовремено, истовремено али не заједно, три дечака". И у Травничкој хроници (1945) налазимо сегмент сличне семантике, у ком је фокализатор „странац”, Другост:

,- Како је могућно, - питао је Дефосе, - да се ова земља смири и среди и да прими бар онолико цивилизације колико њени најближи суседи имају, кад је народ у њој подвојен као нигде у Европи? Четири вере живе на овом уском, брдовитом и оскудном комадићу земље. Свака од њих је искључива и строго одвојена од осталих" (Андрић 1961: 343).

Реч је, дакле, о Андрићевој „опсесивној теми”, коју у различитим остварењима настоји да прикаже у нешто другачијем контексту. Радња Травничке хронике обухвата догађаје од 1806. до 1814. године, приповетка „Три дечака” смештена је у 1888, док „Писмо из 1920. године” тематизује догађаје између 1920. и 1938. Само поменута три дела заједно граде широку временску перспективу живота у Босни, од почетка 19. века готово до почетка Другог светског рата. Андрић је у своме књижевном стваралаштву видимо замишљен над - трансвременским идентитетом босанског човека. При томе писац у поменутим делима даје мање-више исти одговор: трајно обележје човека у овој земљи је одсуство толеранције према сународнику који исповеда другу веру. 


\title{
Одлике нарације у односу на конструисање етничких идентитета у приповеци „Три дечака”
}

\author{
Уметник треба да буде у свом делу као бог у свемиру, невидљив а свемоћан; нека се \\ свуда осећа, али нека се не види. (Флобер, Писма)
}

У причи „Три дечака” заступљена је аукторијална приповедна ситуација, иначе честа у целокупном делу нобеловца. Могло би се рећи да казивач у делу поседује свезнање, иако на моменте ствара привид о томе да само делимично познаје ток збивања. Он говори о ономе што је спољашње и видљиво, али његово приповедање не би се могло дефинисати као „бихејвиористичко”, јер познаје и мисаони свет јунака (на пример: „Све три ове куће, тихе и слабо осветљене, изгледају као замрле, али варају својим изгледом. У свакој од њих има живота и немира, ако не у покретима, свакако у мислима и речима" (Андрић 2012: 287).

Тихомир Брајовић у студији „Андрићев хронотоп”, промишљајући о романима овог аутора, говори о „двострукости концепта времена”: „На једној страни је свјетскоисторијско, 'површно-променљиво' вријеме које зависи од таштине политичких дешавања и појединаца, а на другој - 'непроменљиво', трајно поновљиво вријеме надисторијске или неисторијске категоријалности [...] По нашем суду, овај значајни аспект Андрићевих романа произилази [...] из [...] хронотопске структуре приповиједања. На једној страни је глобални простор који продире у забачену провинцију путем важних, општеутицајних дешавања што стварају дотад непознати осјећај за историјско, или - боље речено - cвјеmскоисторијско вријеме; на другој страни је, пак, тај ограничени, сужени простор у којем, упркос свему, опстаје њему иманентно неисторијско осјећање времена" (Брајовић 1993: 77). Чини се да би се управо предочени концепт могао применити и на приповетку „Три дечака”. У том погледу знаковит је наредни одељак из приче, у ком наратор сугерише да босански град - где је, посетом аустроугарских званичника, продрло глобално историјско време - истог дана, након одласка принца и његове супруге, наставља да живи у ритму свога неисторијскога времена. Другим речима, приповедач имплицира да конзистентно, трајно поновљиво (неисторијско) време одолева свим променама у друштвено-политичком аспекту Босне и представља један од - могло би се рећи - несвесних механизама очувања етничког идентитета Сарајлијаิ у делу:

„И то је било све. Сва су та сјајна и велика господа нестала негде, нагло као што су и дошла, као да су у земљу пропала и то не овде у овом истом граду него негде на другом крају света. И све је одједном пројурило, угасло, умукло, али тако одједном да је живот остао много једноличнији него раније, долина ужа, брда виша и тврђа, не трепте више од звука, небо без сјаја [...] Можда је неко још, седећи за вечером, поменуо 'царевог сина и цареву снаху', па је свак прешао на своје дневне навике и обичаје” (Андрић 2012: 286-287).

Социолог Антони Смит истиче да су верске заједнице често тесно повезане са етничким идентитетом: „Мада су 'светске религије' настојале да прекораче и укину етничке границе, већина верских заједница подударала се с етничким 
групама [...] Католици и протестанти у Северној Ирској, Пољаци, Срби и Хрвати [...] спадају у многе етничке заједнице чији се идентитет заснива на верским мерилима диференцијације” (Смит 1998: 20). Да је вера у приповедном свету дела „Три дечака” основ идентитета - те да је извор сукоба међу ликовима различитог порекла - у наредном сегменту се експлицира:

„Од три поменуте куће у том сокаку највећа је Авдаге Сенабије, типична сарајевска кућа имућнијег мислимана, бела, на спрат, са пространом дивананом у мушепцима и богатом зеленилу старе лозе, са белом авлијом, ограђеном високим зидом. Са страна где нема зида подигнута је висока дрвена ограда. Јер, за последњих десетак година почеле су у ову улицу да досељавају хришћанске и јеврејске породице. Неки су се муслимани због тога иселили; Авдага је остао, али је морао оградити кућу тако високом оградом да би је заштитио од свакојаких погледа" (Андрић 2012: 287).

Савремена имаголошка проучавања надахнута су постструктуралистичком мишљу, услед чега немају за циљ да открију објективну истину (која не постоји), већ тумаче и декодирају субјективне, динамичне перспективе тј. конструкте (Гвозден 2001: 222); уз то, књижевно дело као такво плод је фикције: оно се заснива на стварности, али не приказује верно „стварни” свет - није његова копија. Ако је навод из приче, бартовски речено, „одраз историје”, могао би се анализирати на следећи начин: до Берлинског конгреса је у Сокаку живело муслиманско становништво; након што је Босна потпала под аустроугарску власт, ту су се почели досељавати хришћански и јеврејски свет. На основу последњег дела („Авдага је остао, али је морао оградити кућу тако високом оградом да би је заштитио од свакојаких погледа") чини се да је приповедном проседеу заступљен слободни неуправни говор, одн. неправи директни (управни) говор. Наратор на тренутак казује из „тачке гледишта” Авдаге Сенабије, улази у његов мисаони свет, и самим тим, казује из перспективе његовог етнитета.

Приповедач се неретко користи овим поступком. Можемо га препознати и у сегменту у ком је пажња усмерена на Петра Мајсторовића: „Газда Петар миче уснама, као да још изговара стихове, а скаче на ноге, налива чашу. После Пјесмарице долази обично на ред Велика Катавасија, јер Петар, како бива старији, све је више склон црквеном него мирском појању” (Андрић 2012: 288). Реч „мирски” стилски је изразито маркирана, стога што је део црквеног лексичког фонда. Како је Петар, условно речено, близак религијском погледу на свет, чини се да се и на цитираном месту у тексту сужава (идеолошка) позиција из које се казује. Приповедач мења перспективе и тако се наизменично усредређује на свест опречних тачки гледишта; у том вишегласју се огледа његова модерност.

Примећујемо да се сужавање перспективе на психологију ликова у начелу реализује тако да је секвенца у којој се прожимају глас лика и наратора у вези са проблематиком етничког идентитета и са (антагонистичким) односом према Другости. Наратор „улази” у мисаони свет јунака̂ како би се у тексту „конструисао” непосреднији увид у природу антагонизма православац-католик-муслиман. С једне стране, он препушта говор ликовима, цитира њихове речи, с друге, у виду доживљеног говора демистификује унутрашњи живот јунака. Ова два начина рељефизације ликова у делу су свакако комплементарна. 
Југословенски етнопсихолог Владимир Дворниковић у огледу „Је ли наш народ религиозан” закључује како религија постаје духовном споном, путем и начином за стварање, дизање и одржавање држава" (Дворниковић 1937: 177). У складу са тим, Петар пева сакралне песме пре свега у тежњи за очувањем свог етничког идентитета. Православље (али и ислам и католочанство) у делу су средства борбе са становништвом другачијег порекла, нарочито када је како Андрић у делу показује - идентитет босанског човека „контаминиран” спољашњим утицајима, тј. управом Двојне монархије.

Кулминацију остварења представља „вербални” „сукоб” између Авдаге Сенабије и газда-Петра, односно између Петра и хоџе. При томе није реч о расправи класичнога типа, већ о „препирци” реализованој на физичкој дистанци, преко прозора. Визури ових јунакаิ иманентан је суперлативни аутоимаж: свако од њих верује да су управо његова религијска уверења правоверна. У складу са схватањем Владимира Дворниковића, ликови религију користе као (идеолошко) средство у борби против „неверничког” народа. Док је код Авдаге и хоџе заступљен ,религијски” дискурс, Петар чита и песмарицу о турско-црногорском ратовању и тако се на посредан начин позива на „монументалну историју” колектива ком припада. Приповедач овде показује да између припадника различитих конфесионалних група у Сарајеву онога доба - нема правог дијалога ни комуникације, већ има само презира и неразумевања. Монолошки карактер „расправе” јунака, дакле, у колизији је са полифоном, дијалошком природом приповедне технике у приповеци. Наративна инстанца, видимо, на веома суптилан начин позива на дијалог и промишљање о Другости.

Ако пажљиво читамо сегменте Андрићевог остварења у којима се говори о „препирци” јунакаิ, чини се да наратор једним сегментом, у извесном смислу, вреднује садржај своје приче. Више пута се истиче да се узбуђени, узнемиренигазда Петар натпевава са „невидљивим хоџом”, који је „негде у тами и даљини”. Синтагмом „невидљиви хоџа” наглашава се најпре да муслимански свештеник није у Петровом видокругу. Могло би се рећи и да у тим речима има и ироније: у употреби и понављању ове помало комичне синтагме крије се приповедачев подсмех уперен према Петру и његовој солилоквијумској „расправи” са хоџом.

У последњем делу приче радња се премешта у Катехетски дом, где се води „нека дуга и безизгледна политичка препирка” (Андрић 2012: 288). Из чије перспективе је полемика без изгледна, одн. бесмислена? Не можемо са сигурношћу тврдити. Даље, сазнајемо да су тројица катехета и жупник Фишић „,[...] избегавали [...] да отворе прозор, како се препирка не би чула у комшилуку друге вере" (Андрић 2012: 288). Може бити и да је слободни неуправни говор приповедачев алиби за исказивање сопствених уверења. То је, дакле, у причи „Три дечака” још једна функција доживљеног говора: не можемо бити сигурни да ли је у одређеном сегменту реч о говору „кроз јунака” или о казивачевом коментарисању конкретне ситуације. У том аспекту је тумачење нарације „склизак” терен. Примећујемо да је, поред поменуте „адаптибилности”, и двосмисленост репрезентативна одлика приповедног проседеа у делу. 
О томе сведочи и одељак у коме су на сликовит и сугестиван начин описане топографске одлике „стрме”, „кратке” и „кривудаве”, условно речено, улице: „Тај Дедагин сокак је калдрмисан у виду широких степеница, у њему је мали број кућа, а он сам је не само стрм него и добро нагнут на једну страну, тако да се калдрма степеништа лепезасто шири и личи на ребра на скелету неке претпотопне животиње, који је једним делом потонуо у земљу" (Андрић 2012: 286). Потоп се тематизује и у јудео-хришћанској и у исламској светој књизи, те увиђамо да је реч о двозначном исказу: на основу истакнутог детаља не можемо закључити из које (конфесионалне) позиције наратор говори.

Свезнајући приповедач се употребом одређених лексема приближава интерној тачки гледишта, односно перцепцији и светоназору јунака̂, чиме се редукује психолошка дистанца између казивача и ликова. Он се неретко користи етнолектом, тј. ,језичким особинама које карактеришу говорника по етничкој припадности” (Ковачевић 2012: 288). У причи су заступљени турцизми, речи иманентне лексичком фонду Сарајлијаิ, и то превасходно онима који су исламске вероисповести: „сибијан”, „ифтар”, „диванана”, „ђердан” итд. Помним читањем приповетке уочићемо две речи написане ијекавицом: код казивачевог приказивања догађања у кући Авдаге Сенабије: „Вечерас је у 'женској страни' код њих велико сијело" (Андрић 2012: 288); при завршетку Андрићевог дела, у сегменту у ком је заступљен слободан неуправни говор дечака-католика Филипа: „Онако савијен од нејасне мисли и болног несналажења, дечак је $u$ не хтијући морао да слуша узвике и искидане реченице из трпезарије” (2012: 289), где је вођена поменута „безизгледна политичка препирка”. Обратимо пажњу на други пример: ако је у наведеном одељку реч о доживљеном говору, због чега и у неким претходним видовима слободног неуправног говора није употребљен ијекавизам (нпр. читамо да катехете и жупник Фишић нису отварали прозор „како се препирка не би чула у комшилуку друге вере”)? На претходно постављено питање могли бисмо одговорити на три начина. С једне стране, у сегменту где се појављује облик „не хтијући” примењен је доживљени говор, док је пример у ком уочавамо екавизам „вера“ казивачев коментар на конкретну ситуацију. C друге стране - ако се сетимо да Андрић причу „Три дечака” сматра „скицом” предочена „произвољност” у употреби облика може бити недорађеност, превид, стилска неравнина. А може бити и - интенционална: према Бахтину ,уплитање 'изворних' елемената у неуправни говор показује пишчево умијеће у остваривању 'разнолике игре говора, њихово узајамно запљускивање и њихово узајамно заражавање' (према Ковачевић 2012: 314). Коначно, поред етнолекта, казивач употребљава и социолект, и то онај који је карактеристичан за дечји израз, у одељку у ком коментарише духовну атмосферу међу најмлађим становницима Сарајева након „параде”: „За већину тих дечака остало је само још да се иде сувише добро знаној кући [...] да се, са задоцњењем, поруча убоги босански ручак" (Андрић 2012: 286).

Приповедна стратегија Андрићевих дела неретко подразумева и употребу парентезе, стилског средства које има метафункцију, те „упућује на 'свесну је- 
зичку делатност говорног лица коме је циљ да разоткрије себе и чињеницу да о нечему говори и да се то о чему говори односи на управо употребљени језички израз”” (према Брајовић 2009а: 55). У причу „Три дечака” „уметнуте” су две парентезе:

„Све тврђаве које сачињавају венац око Сарајева осветљене ђерданима трептавих светлости. На стрмим падинама невидљивих брда, изједначених са тамом, подрхтавају великим правилним словима од светлости натписи: Rudolf-Stefanie (а изнад иртице која везује два имена: иарска круна), затим Hoch! Willkommen!” (Андрић 2012: 287);

„До газда-Петрове куће диже се зеленкасто обојена кућа новијег типа [...] То је Катехетски дом, својина католичке цркве. [...] У кући и око ње влада увек мир. Једини звук који свакодневно продире из те куће то је свирка хармонијума, па и она пригушена и жаловита, трома и спора као птица ниска лета. (Због те свирке највише је мрзео Авдага Сенабија свој нови хришћански комшилук)" (Андрић 2012: 287).

Реч је, заправо, о „неправим” или непотпуним парентезама - паремболама, стога што су синтаксички и значењски повезане с главним реченицама (везником „a”, односно предлогом „због”), услед чега не удовољавају дефиницијском одређењу парентезе, по ком садржај интерполиран у заграду,',нема никакве синтаксне свезе с реченицом у коју је уметнут" (према: Брајовић 2009а: 41). У првој паремболи не успевамо да пронађемо дубља значења - као да је сасвим случајна и несмислена. Њена евентуална сврховитост би могла бити у томе да одаје утисак „насумичности”, како би на принципу аналогије код читаоца исти дојам створила и друга, умногоме индикативнија парентеза. Пре него што анализирамо други „уметак”, подсећамо да се у Андрићевој приповеци, приликом описивања Сокака, вели и следеће: „[...] за последњих десетак година почеле су у ову улицу да досељавају хришћанске и јеврејске породице” (Андрић 2012: 287), тј. да је на томе месту првобитно живело муслиманско становништво. Српски нобеловац у докторској дисертацији, Развој духовног живота у Босни под утищајем турске владавине, објашњава како хришћани ,у својим кућама не смеју гласно и снажно звонити, већ једино умерено. У њима [могу - М. М.] само полугласно да певају” (Андрић 2011: 46). Када је Сарајево потпало под „k. u. k.” управу, наведена правила су, можемо претпоставити, престала да важе. Следствено, из Катехетског дома чује се гласна музика, што, с обзиром на пређашње стање - у ком је муслимански живаљ био на известан начин повлашћен - изазива срџбу код Авдаге Сенабије. Примећујемо да је у загради употребљен веома експресиван глагол, „мрзети”, који није у складу са одмереним и „објективним” дискурсом наратора. Употреба глагола „мрзети” (екавски облик!) може се објаснити као још један пример доживљеног говора у приповеци, на основу чега, можемо претпоставити да у причи „Три дечака” није реч о парентези као о „,ауторском коментару".

Амерички теоретичар и књижевни критичар Вејн Бут у студији Реторика прозе образлаже како је нужан елемент сваког дела „пишчево манипулишуће присуство” (Бут 1976: 34): „Романописац који одабере да исприча ову причу не може истовремено да прича ону; усредсређујући наше занимање, наклоност или саучешће на један лик, он неминовно искључује неки други из нашег занимања, 
наклоности или саучешћа" (Бут 1976: 95). Пишчев суд је у књижевном делу „увек присутан, увек очигледан за сваког ко уме да га потражи” (Бут 1976: 35). Наклоности и интересовања аутора „Три дечака” огледају се пре свега у избору теме дела, а то је сучељеност људи различите вере у Сарајеву крајем 19. века. Затим у нијансирању и усложњавају политичких прилика у босанском граду, чиме се сугерише да идентитет човека у прошлости ове балканске земље - али и у актуелном тренутку - био вишеструко угрожен; на тај начин се донекле оправдавају ликови који не гаје наклоност према Другости. Суд аутора приметан је и у приказивању „препирке” јунака у којој недостаје кључни део расправе - дијалог. Коначно, различитим „скривеним” сигналима на језичко-стилском плану нарације писац показује извесну дозу „емпатије” према својим ликовима, али и отклон од одређених облика њиховог међусобног опхођења.

Четврту етнију у причи чине Јевреји, али се композицијом и доминантним садржајем акцентују оне релације које су до сада у раду тумачене. Ауторски приповедач на тај начин сугерише да је однос православца, католика и муслимана према Јеврејима мање проблематичан од узајамних односа између ове три верске групације. У складу са тим, овај етнитет се у делу помињу „успутно”, и то само два пута. Први пут при почетку приповетке, у сегменту у ком се говори о хоџи који не успева да умири своје ученике приликом дочека „гостију”: „Фанатичан и упоран човек који још није могао да се прилагоди новом стању, он није никако пристајао да његова деца вичу: живио! као и хришћанска и јеврејска деца" (Андрић 2012: 286); други пут у одељку где се приказује окончање велике свечаности:

„Бањски бријег је слабо осветљен као и све остале стрме махале где нема званичних зграда ни чиновничких станова. По прозорима синагоге на Мејташу горело је неколико невешто размештених свећа, па их чувар погасио још пре него што су догореле, мало по урођеном нагону штедње, али још више због тога да би могао да оде да спава а да не брине о светлости на синагоги и опасности од пожара" (Андрић 2012: 287).

И Јевреји, дакле, имају удела у анимозитету који се тематизује у делу, али је он незнатан, те се не развија. У другом цитату Јеврејин је представљен стереотипно, као штедљивац, односно као човек који рационално располаже ресурсима, што је представа која нема дубљих импликација на средишњу тему приповетке.

Иако нам се спрва чинило да је прича „Три дечака” Иве Андрића значењски готово једнодимензионална, а у погледу нарације традиционална и конвенционална, анализом њене приповедне страгетије утврђено је супротно. Између осталог, примећено је да је заступљена промена тачке гледишта, што можемо сматрати модерном наративном одликом дела. Уочено је да причу казује добро информисан ауторски приповедач, који није потпуно „одсутан”, те нема апсолутну дистанцу од онога о чему говори, већ, посредством извесних коментара и других текстуалних индикатора, показује свој став према „конфлитку” између православца, католика и муслимана. Он имплицитно критикује и осуђује поменуту сучељеност, али уједно и оправдава Сарајлије, који се боре за очување свог 
идентитета у веома замршеној мрежи односа између Истока и Запада. У самом тексту не постоје недвосмислени показатељи из које (идеолошке) перспективе казивач проговара; ипак, показали смо да у његовом дискурсу постоји извесна доза емпатије према босанском свету с краја 19. века. Ако се сетимо стеретотипне слике Балкана коју наводи Весна Голдсворти, а по којој је овај део југоисточне Европе место где су људи међусобно сукобљени услед исповедања различитих религија, сматрамо да Андрић причом „Три дечака” надилази ту представу, и то управо предоченим „нијансирањем” става према анимозитету у наративу: у делу је изграђен не амбивалентан однос према сучељености ликова већ изразито комплексан увид у читаву проблематику.

\section{ЛИТЕРАТУРА}

Андрић 1961: И. Андрић, Травничка хроника, Београд: Просвета.

Андрић 2011: И. Андрић, Дисертација. Есеји и критике, Подгорица-Крагујевац: Штампар Макарије.

Андрић 2012: И. Андрић, Сабране приповетке, Жанета Ђукић Перишић (приредила). Београд: Завод за уџбенике.

Брајовић 1993: Т. Брајовић, Андрићев хронотоп. Нови Сад: Летопис Матице српске, год. 169, књ. 451, св. 1, Нови Сад, 71-81.

Брајовић 2005: Т. Брајовић, Реторика приповедне перспективе у међуратним новелама Иве Андрића, у: Т. Брајовић (2005). Облици модернизма, Београд: Чигоја штампа, 173-204.

Брајовић 2009а: Т. Брајовић, Поетика парентезе, у: Т. Брајовић (2009). 3aборав и понављање: амбивалентно лище модернитета у роману На Дрини ћуприја, Београд: Нолит.

Брајовић 2009б: Т. Брајовић, Полиморфност приповедања, у: Т. Брајовић (2009). Заборав и понављање: амбивалентно лице модернитета у роману На Дрини ћуприја, Београд, Нолит.

Брајовић 2012: T. Brajović, Komparativni identiteti: srpska književnost između evropskog i južnoslovenskog konteksta, Beograd: Službeni glasnik.

Бут 1976: V. But, Retorika proze, Beograd: Nolit.

Гвозден 2001: В. Гвозден, Полазишта и циљеви имаголошког приступа проучавању књижевности, Нови Сад: Зборник Матице српске за књижевност и језик, књ. 49, св. 1/2, Нови Сад: Матица српска, 211-224.

Голдсворти 2005: V. Goldsvorti, Izmišljanje Ruritanije: imperijalizam mašte, Beograd: Geopoetika.

Дворниковић 1937: В. Дворниковић, Је ли наш народ религиозан, Нови Сад: Летопис Матиие српске, год. 111, књига 348, св. 2, Нови Сад, 174-189. 
Ковачевић 2012: М. Ковачевић, Лингвостилистика књижевног текста, Београд: Српска књижевна задруга.

Константиновић 2006: R. Konstantinović, Filosofija palanke, Beograd: Otkrovenje.

Милутиновић 2009: 3. Милутиновић, Неспоразум је правило, разумевање је чудо: Травничка хроника Иве Андрића, Београд: Свеске Задужбине Иве Андрића, 26, Београд, 119-159.

Палавестра 1997: П. Палавестра, Трагови Андрићевих предсказања, Београд, Свеске Задужбине Иве Андрића, 13, Београд, 16-19.

Рот 2000: K. Rot, Slike u glavama: stereotipi, mitovi, identiteti sa etnološkog stanovišta, y: K. Rot (2000). Slike u glavama,Beograd: Biblioteka XX vek.

Смит 1998: A. D. Smit, Nacionalni identitet, (preveo) Slobodan Đorđević, Beograd: Biblioteka XX vek.

Штанцл 1987: Ф. Штанцл, Типичне форме романа, Нови Сад: Књижевна заједница Новог Сада.

Magda G. Milikić

ETHNIC IDENTITIES IN ANDRIĆ'S SHORT STORY „TRI DEČAKA”: NARRATIVE ANALYSIS

Summary

In the paper we applied imagologic approach of interpretation on Andrić's short story,,Three boys" (,Tri dečaka”). We analysed narrative strategy in the story, trying to emphasize those aspects that are related to process of construction of characters' ethnic identities. The analyse in the paper is based on sociological, ethnopsychological, philosophical and literary theoretical insights. By analysing narrative characteritisc, we strived to establish if there are stereotypes about ethnicities in the story and if they are revaluated.

Keywords: Ivo Andrić, „Tri dečaka”, imagology, ethnic identity, religion, narrative strategy. 